\title{
Expression of the Bacterial Catalase Genes During Sinorhizobium meliloti-Medicago sativa Symbiosis and Their Crucial Role During the Infection Process
}

\author{
Alexandre Jamet, Samuel Sigaud, Ghislaine Van de Sype, Alain Puppo, and Didier Hérouart \\ Laboratoire de Biologie Végétale et Microbiologie, CNRS FRE 2294, Université de Nice Sophia-Antipolis, Parc Valrose, \\ 06108 Nice cedex 2, France
}

Submitted 2 July 2002. Accepted 20 November 2002.

\begin{abstract}
Sinorhizobium meliloti possesses three distinct catalases to cope with oxidative stress: two monofunctional catalases (KatA and KatC) and one bifunctional catalase-peroxydase (KatB). The katB gene is constitutively expressed during growth in batch culture and is not induced under oxidative stress conditions. In contrast, the expression of katA and $k a t C$ genes is mainly regulated at the transcription level in these conditions. A differential expression of $k$ at genes was observed during the development of the nodule. A high expression of $k a t A$ gene was detected in bacteroids, suggesting that the nitrogen-fixation process induces a strong oxidative stress. In contrast, bacteria express $\mathrm{katB}$ and $\mathrm{katC}$ genes and not the $\mathrm{H}_{2} \mathrm{O}_{2}$-inducible katA gene in infection threads despite the detection of $\mathrm{H}_{2} \mathrm{O}_{2}$ around the bacteria. A katB katC double mutant nodulated poorly and displayed abnormal infection. After nonefficient release into plant cells, bacteria failed to differentiate into bacteroids and rapidly underwent senescence. Our results indicate that these two catalases are essential for the establishment of the symbiosis. They also suggest that the bacteria are in a nonexponential growth phase in infection threads and corroborate previous studies on the growth rate of bacteria inside the plant.
\end{abstract}

Sinorhizobium meliloti is an aerobic gram-negative bacterium from the rhizosphere able to infect roots of Medicago species and develop a symbiosis. During this process, a sophisticated exchange of recognition signals occurs between both partners (Long 1996). In response to flavonoids secreted by legume roots, the microsymbionts produce nodulation factors, which are essential for the formation of a new organ, the root nodule (Lerouge et al. 1990; Stougaard 2000). Inside the plant cell, bacteria differentiate into their symbiotic forms, the bacteroids that are able to reduce atmospheric nitrogen to ammonia. The key enzyme of nitrogen fixation, nitrogenase, is rapidly and irreversibly inactivated by oxygen. To avoid this inactivation, a diffusion barrier in the cortex of nodules limits permeability to oxygen, which is delivered to bacteroids by leghemoglobin, a plant oxygen carrier. Despite this efficient system to reduce the diffusion of an excess of oxygen to the bacteroid, a high rate of respiration is necessary to supply the energy required by the nitrogen reduction process. This leads to the production of reactive oxygen species such as superoxide radicals $\left(\mathrm{O}_{2}^{-}\right)$and hydrogen peroxide $\left(\mathrm{H}_{2} \mathrm{O}_{2}\right)$. In addition, an oxidative burst including an accumulation of $\mathrm{O}_{2}^{-}$and $\mathrm{H}_{2} \mathrm{O}_{2}$ occurs

Corresponding author: D. Hérouart; E-mail: herouart@unice.fr. during the early stages of the symbiotic interaction, especially in the infection threads (Santos et al. 2001).

The response of both free-living bacteria and bacteroids to the toxic form of oxygen is an important factor for nodulation and nitrogen fixation. The dismutation of $\mathrm{O}_{2}^{-}$to $\mathrm{H}_{2} \mathrm{O}_{2}$ and $\mathrm{O}_{2}$ is catalyzed by an atypical superoxide dismutase SodA in $S$. meliloti (Santos et al. 1999). Disruption of the sodA gene affected the symbiotic properties of $S$. meliloti in alfalfa. Most mutant bacteria nodulated poorly and did not reach the differentiation stage of nitrogen-fixing bacteroid (Santos et al. 2000). As other root nodule bacteria, $S$. meliloti free-living cells had higher susceptibility to $\mathrm{H}_{2} \mathrm{O}_{2}$ than most of the other genera of aerobic or facultative anaerobic bacteria (Hérouart et al. 1996; Ohwada et al. 1999). Analysis of $\mathrm{H}_{2} \mathrm{O}_{2}$-scavenging enzymes on native gels revealed that, in $S$. meliloti, the dismutation of $\mathrm{H}_{2} \mathrm{O}_{2}$ into $\mathrm{O}_{2}$ and $\mathrm{H}_{2} \mathrm{O}$ occurs through the action of three different catalases, two monofunctional catalases (KatA and KatC) and one bifunctional catalase-peroxidase (KatB) (Hérouart et al. 1996). A switch of catalase activity pattern occurred during bacterial growth in minimum medium (Sigaud et al. 1999). KatA was mainly detectable during the exponential phase while, during the stationary phase, KatC activity increased as KatA activity gradually decreased. KatB activity was detected throughout the growth of bacteria in minimum medium and represented around $90 \%$ of the total catalase activity, suggesting an important role of this bifunctional catalase in free-living bacteria. Analysis of $S$. meliloti catalase profiles after several treatments that are known to produce an oxidative stress has shown an increase in KatA activity in response to exogenous $\mathrm{H}_{2} \mathrm{O}_{2}$. In contrast, an induction of katC gene was only observed after bacteria had been exposed to heat stress, salt stress, or ethanol. Analysis of other root nodule bacteria such as Bradyrhizobium japonicum, S. fredii, Rhizobium leguminosarum bv. trifolii, and $R$. leguminosarum bv. Phaseoli, on native gel also revealed the presence of three catalases. The catalase activity of these bacteria profiles also varied either in the presence of $\mathrm{H}_{2} \mathrm{O}_{2}$ in the environment (Ohwada et al. 1999), during growth, or both, suggesting a cell-density regulation of catalase (Crockford et al. 1995). However, the role of each catalase in the response of bacteria to oxidative stress and especially during the symbiotic interaction is still unknown. In S. meliloti, single katA or $k a t C$ mutants showed similar nodulation and nitrogen fixation capacities as compared with a wild-type strain (Sigaud et al. 1999). In contrast, a dramatic decrease of nitrogen fixation capacity in a katA katC double mutant was already observed (Sigaud et al. 1999). In this paper, the expression of the three catalase genes is analyzed in free-living cells and during the establishment and the maintenance of nitrogen-fixing nodules. 
Moreover, the analyses of nodules incited by double catalase mutants are presented at structural and ultrastructural levels.

\section{RESULTS}

Cloning and analysis of the katB gene in S. meliloti.

Three catalase genes have been predicted, based on the analysis of the complete genome of $S$. meliloti strain Rm1021 (Galibert et al. 2001). The sequence of the megaplasmid pSymA (Barnett et al. 2001) reveals the presence of an open reading frame showing high homology with other bacterial catalase-peroxidase, such as Mesorhizobium loti (69\% identity) and Escherichia coli HPI catalase (58\% identity). However, before the publication of the Rm1021 genome sequence, we amplified a polymerase chain reaction (PCR) fragment (SmkatB) using a nested-PCR strategy with three degenerated primers that were deduced from a consensus sequence of five bifunctional catalase-peroxidases as described below. SmkatB was used as probe to screen a genomic library and to localize $k a t B$ on a 3-kb SmaI-ApaI DNA fragment (subclone pBSKB1). Alignment of the deduced amino acid sequences of $k a t B$ and the published sequence (Sma2379) revealed one punctual mutation $(\mathrm{T}->\mathrm{G})$ resulting in one substitution at amino acid level (Met364 ->Arg364). The Met364 is conserved in all bacterial catalase peroxidases published so far. Specific primers were synthesized to amplify this genomic region, using Rm1021 DNA as template (discussed below). The amplified fragment was purified and was cloned in the pGEM-T vector. The sequencing of four independent recombinant plasmids indicates that this punctual mutation is present in the pSymB of strain Rm1021. Analysis of Rm1021 cell extracts on native gel using the DAB-negative coloration of catalase profiles showed that the achromatic band corresponding to the KatB activity was still present despite the Met364 substitution (Fig. 1B). However, higher KatA and lower KatB activities were observed on native gel for strain Rm1021 compared with GMI211 (Fig. 1A) and Rm5000 (Sigaud et al. 1999). The sequence of the region Sma2379 can be noted as katB.

\section{Phenotypic of katB mutant in free-living conditions.}

To evaluate the effect of $k a t B$ disruption on free-living phenotype, a transcriptional katB::lacZ fusion was constructed by insertion of a promoterless $l a c Z$ cassette into the $k a t B$ coding region (discussed below). This fusion was transferred into strain GMI211 ( $\mathrm{LacZ}^{-}$) by conjugation, and the disruption of $k a t B$ was confirmed by Southern analysis of the recombinant mutant strain (GKBZ01). The total catalase activity in GKBZ01 (14.2 $\pm 4.3 \mathrm{U}$ per $\mathrm{mg}$ of proteins) during the exponential growth phase was 2.5 -fold less than in control strain

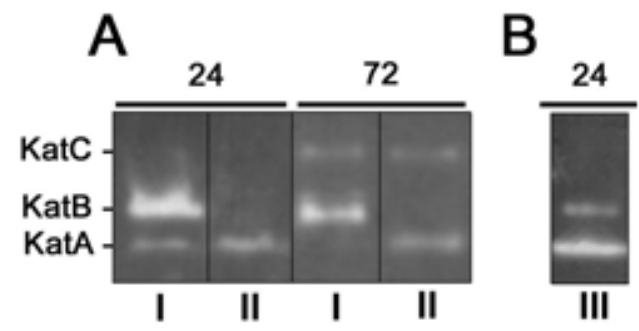

Fig. 1. Catalase activity patterns of Sinorhizobium meliloti strains. Stationary cultures were inoculated in fresh LB-MC medium to an initial optical density at $600 \mathrm{~nm}$ of 0.01 . Cell extracts were prepared from GMI211 (I), the katB mutant GKBZ01 (II), and Rm1021 (III) strains after $24 \mathrm{~h}$ (midexponential phase) and $96 \mathrm{~h}$ (stationary phase). Proteins $(30 \mu \mathrm{g})$ were submitted to electrophoresis on a native polyacrylamide gel $(7 \%)$ that had been stained for catalase activity. The positions of KatA, KatB, and KatC are indicated according to Sigaud and associates (1999).
GMI211 (36 $\pm 6.7 \mathrm{U}$ per $\mathrm{mg}$ of proteins). In contrast, no significant difference in total catalase activity was detected in either strain when bacterial extracts were prepared from bacteria in stationary phase $(20.6 \pm 7.9$ and $17 \pm 7.2 \mathrm{U}$ per $\mathrm{mg}$ of proteins, respectively). Analysis on native gel of catalase profiles of cell extracts of GMI211 and GKBZ01showed that KatB activity was present in GMI211 (I) and absent in GKBZ01 (II), confirming that this gene effectively encodes KatB (Fig. 1A). Introduction of a stable plasmid containing $k a t B$ into GKBZ01 restored the KatB activity (data not shown). Growth curves of these two strains on either LB-MC or minimum medium were not significantly different (data not shown). The deficiency of KatB was not compensated for by the induction of either KatA or KatC or both monofunctional catalases in midexponential phase (Fig. 1A; 24 h). In contrast, in stationary phase (Fig. 1A; $72 \mathrm{~h}$ ), KatA activity was still detected in GKBZ01 and not in GMI211 despite the induction of KatC in both strains, indicating a deregulation of the switch-off of KatA in the katB mutant strain and thus providing an explanation for our data on total catalase activities.

\section{Growth and catalase gene expression.}

To complete our knowledge on the expression of each catalase gene during growth, two new recombinant strains harboring promoter-lacZ fusions were constructed. The transcriptional katC::lacZ fusion described previously (Sigaud et al. 1999) was introduced in the GMI $211 \mathrm{LacZ}^{-}$strain using triparental mating, resulting in the recombinant GKCZ01 strain. In parallel, a transcriptional katA::lacZ fusion was constructed and cloned in the suicide plasmid pSUP202 in order to obtain the recombinant GKAZ01 strain. No difference in growth on LB-MC medium was observed between the three kat::lacZ recombinant strains and the GMI211 control strain (data not shown). $\beta$-galactosidase activities were determined during their growth. A fourfold increase of $\beta$-galactosidase activity was observed in the stationary phase of GKCZ01 confirming that the growth-dependent KatC regulation is mainly transcriptional in $S$. meliloti. No significant modification of $\beta$-galactosidase activity was detected in GKBZ01, indicating that KatB could be mainly considered as a housekeeping bifunctional catalase-peroxidase enzyme (data not shown). In contrast, a threefold greater $\beta$-galactosidase activity was detected during the early exponential phase in GKAZ01 as compared with the very low basic activity during stationary phase (Fig. 2). These data are correlated with the KatA catalase pattern observed in GMI211 on native gel (Fig. 1A), indicating that katA is mainly regulated at a transcriptional level during growth in batch culture.

\section{Oxidative stress and catalase gene expression.}

Previous analysis of a recombinant Rm5000 strain harboring a $k a t C:: l a c Z$ fusion revealed that katC expression is induced by some treatments that are known to induce an oxidative stress, such as heat stress $\left(37^{\circ} \mathrm{C}\right)$, salt stress $(\mathrm{NaCl})$, ethanol, and paraquat (a superoxide-generating compound). On the other hand, no induction of katC by exogenous $\mathrm{H}_{2} \mathrm{O}_{2}$ was observed (Sigaud et al. 1999). A similar expression pattern was observed in GKCZ01 when treatments were applied to bacteria in exponential phase (data not shown). No induction of katB was detected in GKBZ01 following any of the treatments tested in this paper. In contrast, when exogenous $\mathrm{H}_{2} \mathrm{O}_{2}(1 \mathrm{mM})$ was added to the growth medium, a sixfold increase of $\beta$-galactosidase activity in GKAZ01 was measured after $1 \mathrm{~h}(430 \pm 23$ Miller units) as compared with nontreated bacteria (70 \pm 4 Miller units). It is interesting to point out that no induction of any kat gene expression was observed when the oxidative treatments were applied to bacteria in stationary growth phase (data not shown). 
Nodule development and catalase gene expressions.

To investigate the effect of katB disruption on nodulation and fixation capacities of the bacteria, alfalfa seedlings were infected with the null katB mutant GKBZ01 and with GMI211 as control. No significant difference was observed five weeks after infection: $98 \%$ of inoculated plants produced nodules with an average of 10 nodules per plant and an acetylene reduction activity of $53 \pm 5$ nmole $\mathrm{C}_{2} \mathrm{H}_{4}$ per min per mg of fresh weight $(\mathrm{FW})$.

To analyze the expression of each catalase gene during the development of the root nodule, alfalfa seedlings were independently infected by the three strains harboring one transcriptional kat::lacZ fusion (GKAZ01, GKBZ01, and GKCZ01). Strain GMI211 was used as control. Analysis of total $\beta$-galactosidase activity in 6-week-old nodule extracts showed that katA was highly expressed $(3,572 \pm 182$ Miller units per $\mu \mathrm{g}$ of proteins) compared with katB and katC $(545 \pm 101$ and $262 \pm$ 77 Miller units per $\mu$ g of proteins, respectively). The histochemical detection of $\beta$-galactosidase activity was performed using X-gal as substrate (Fig. 3). Three days after infection, analysis of root hairs revealed a blue staining inside infection threads only with strains GKBZ01 and GKCZ01 (Fig. 3B and
C). During the first steps of root infection by $S$. meliloti, an accumulation of $\mathrm{H}_{2} \mathrm{O}_{2}$ has been detected around bacteria inside some infection threads (Santos et al. 2001). However, analysis of plants infected by GKAZ01 revealed no expression of the katA::lacZ fusion inside infection threads (Fig. 3A). Moreover, treatment of roots with exogenous $\mathrm{H}_{2} \mathrm{O}_{2}$ at several concentrations $(0.1 \mathrm{mM}, 1 \mathrm{mM}$, and $10 \mathrm{mM})$ for $1 \mathrm{~h}$ before histochemical staining with $\mathrm{X}$-gal had no effect on katA expression inside infection threads (data not shown). To complete our investigation on the expression of kat genes, 7-day-old and 6-week-old nodules were analyzed (Fig. 3D through $\mathrm{F}$ and $3 \mathrm{G}$ through I, respectively). As expected, no X-gal staining was observed in the meristematic zone of root nodules (I). The katB::lacZ fusion was expressed in several morphological zones: infection (II), fixation (III), and senescent (IV) zones of young and mature nodules (Fig. $3 \mathrm{E}$ and $\mathrm{H}$, respectively). In contrast, the kat $A:$ :lac $Z$ was strongly expressed only in nitrogen fixing bacteroids (Fig. 3G). This result is consistent with our previous analysis of catalase activity pattern in bacteroids. A higher catalase activity (sevenfold) has been measured in bacteroids extracted from 5-week-old nodules than in free-living bacteria, and KatA is the major isoform detectable on native gel in bacteroid protein extract (Sigaud et al.

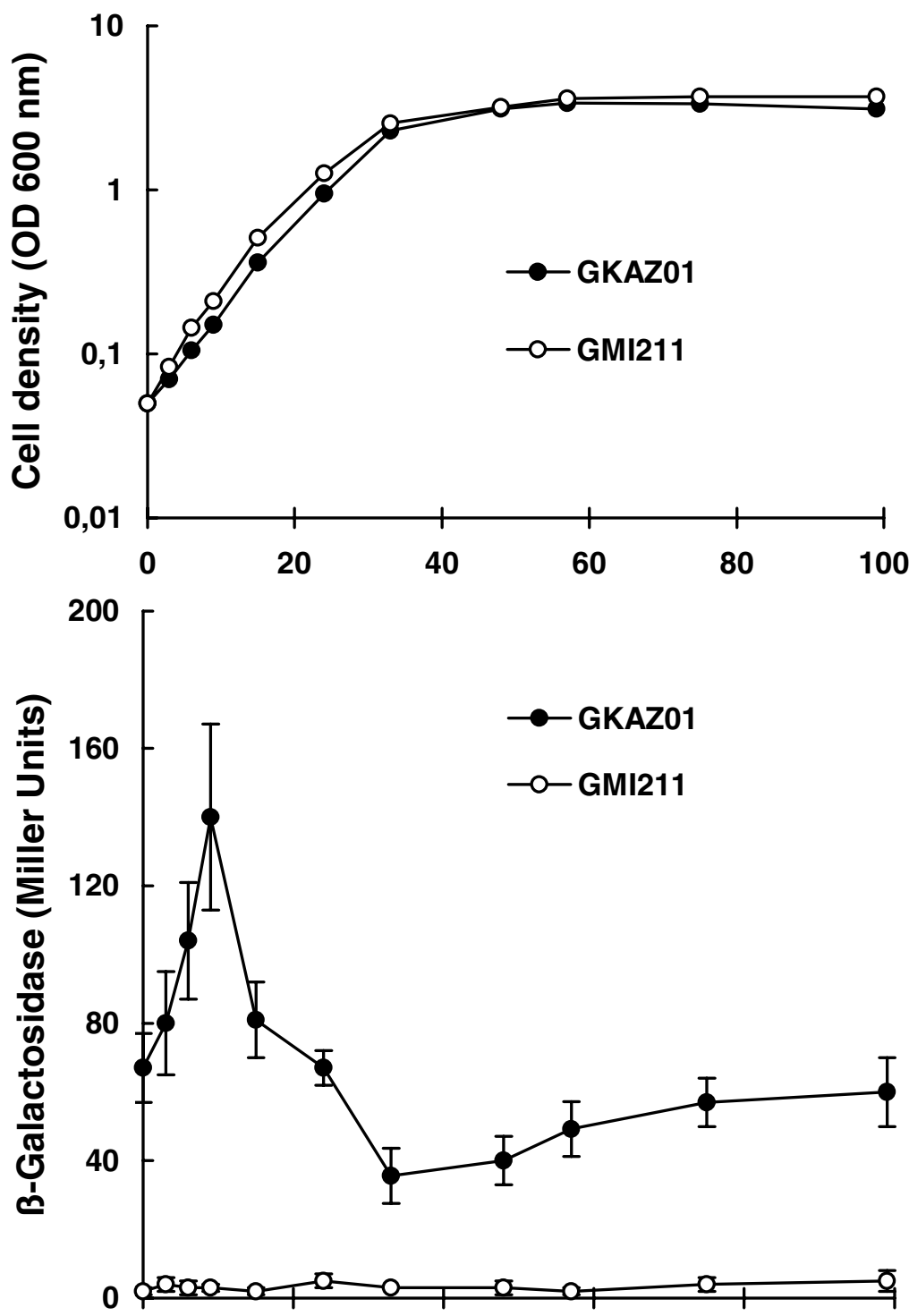

Fig. 2. Growth stage induction of katA gene. Stationary cultures of GKAZ01 (katA::lacZ transcriptional fusion) were inoculated in fresh LB-MC medium to an initial optical density at $600 \mathrm{~nm}$ of 0.05 . At the indicated times, samples were taken to assay $\beta$-galactosidase activity. Values represent averages of three assays. Error bars show standard deviation. 
1999). Finally, the katC::lacZ fusion was expressed in infection zone II and in the interzone II-III of young nodules (Fig. 3F) while, in mature nodules, a blue staining was observed in bacteria of infection zone II and in some bacteria at the extreme limit of zone IV (Fig. 3I).

\section{Symbiotic phenotype of a katB katC double mutant.}

During the first steps of root infection by $S$. meliloti, it appears that both $k a t B$ and $k a t C$ are expressed in the infection threads. Single null mutation of $k a t B$ or $k a t C$ had little effect on bacteria growth, root nodulation, or nitrogen fixation. To in-
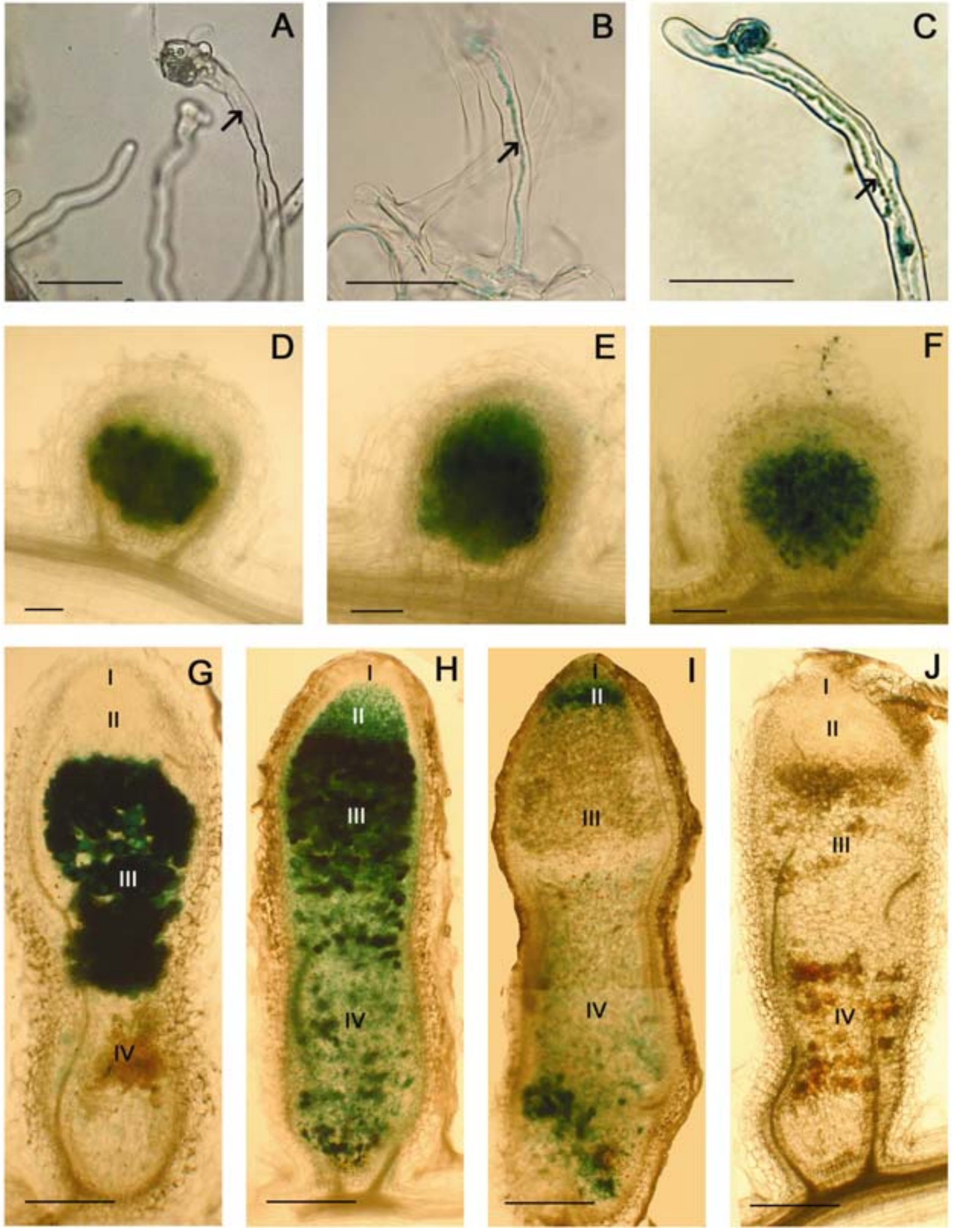

Fig. 3. Histochemical localization of bacterial kat genes expression during Sinorhizobium meliloti-Medicago sativa nodule development. $\beta$-galactosidase activity was detected using X-Gal as substrate for $\mathbf{A}, \mathbf{D}$, and $\mathbf{G}$, katA::lacZ; $\mathbf{B}, \mathbf{E}$, and $\mathbf{H}$, katB::lacZ; and $\mathbf{C}$, $\mathbf{F}$, and $\mathbf{I}$, katC::lacZ fusions in hair roots four days after infection (A through $\mathrm{C}$ ); in 7-day-old nodules (D through $\mathrm{F}$ ); and in 6-week-old nodules (G through I). $\beta$-galactosidase staining of a 6-week-old nodule infected by J, control strain GMI211. Arrows indicate infection threads. Spatial development zones (I, II, III, or IV) are indicated on nodule cross sections. Scale bars $=50 \mu \mathrm{m}$ (A through C), $100 \mu \mathrm{m}$ (D through F), and $200 \mu \mathrm{m}$ (G through J). 
vestigate the combined role of these two catalases, a double mutant strain katB katC (named MK5004) was constructed by conjugation, using the katC mutant as the recipient strain as described below. Disruption of the katB gene was confirmed by Southern analysis of the double mutant (data not shown). In free-living conditions, the growth of the MK5004 strain was slightly affected in LB-MC; doubling time was about 1.4-fold longer, but maximal growth was the same after $50 \mathrm{~h}$ (data not shown). The total catalase activity of MK5004 (7.8 \pm 2.4 U per $\mathrm{mg}$ of proteins) in exponential phase was threefold lower than in control strain Rm5000 (24.2 $\pm 5.6 \mathrm{U}$ per $\mathrm{mg}$ of proteins) and analysis on native gel confirmed the absence of KatB and KatC activities (data not shown).

Only $45 \%$ of plants infected with MK5004 produced nodules. These nodules were white and $75 \%$ of them were small and spherical. In contrast, a high efficiency of nodulation (70 to 90\%) was observed with the wild-type strain Rm5000 and the single $k a t B$ or $k a t C$ mutants. Moreover, the average number of nodules per nodulated plant decreased from 2.75 (Rm5000) to 1.76 (MK5004). Acetylene reduction activity was determined in nodulated $M$. sativa 5 weeks after bacterial infection. A drastic decrease in $\mathrm{C}_{2} \mathrm{H}_{2}$ reduction was observed for the katB katC double mutant ( $3.3 \pm 0.9$ nmole $\mathrm{C}_{2} \mathrm{H}_{4}$ per min per mg of $\left.\mathrm{FW}\right)$ as compared with strain $\mathrm{Rm} 5000\left(65.8 \pm 24.5\right.$ nmole $\mathrm{C}_{2} \mathrm{H}_{4}$ per min per $\mathrm{mg}$ of $\mathrm{FW}$ ). Moreover, this decrease is far greater than that observed for the katA katC double mutant (Sigaud et al. 1999).

\section{Bacteroid differentiation in nodules from katB katC and $k a t A$ katC double mutants.}

Alfalfa nodules from plants infected with MK5003 $\left(\mathrm{katA}^{-}\right.$ $k a t C^{-}$), MK5004 (katB-katC ${ }^{-}$) and Rm5000 (wt) were studied at structural and ultrastuctural levels by optical and electronic microscopy. In nodules obtained after infection with Rm5000, the five typical steps in bacteroid development (type 1 to 5) described by Vasse and colleagues (1990) were observed. The meristematic zone I is bacteria-free. Bacteria released from infection threads in plant cells are surrounded by a peribacteroid membrane in the distal infection zone II (bacteroid of type 1). Bacteroids elongated without dividing in the proximal infection zone II (bacteroid of type 2). In interzone II-III, bacteroids stopped elongating and displayed cytoplasmic heterogeneity (bacteroid of type 3). They showed a higher cytoplasmic heterogeneity and differentiated into a type 4 nitrogen-fixing bacteroid in infected cells of zone III. (Fig. 4A and B). Both symbionts degenerated in the senescent zone IV. Undifferentiated bacteria reinfected plant cells but did not differentiate into bacteroids in the saprophytic zone V (Timmers et al. 2000). The differentiation of bacteroids was blocked at different steps in nodules infected by MK5003 or MK5004.

When compared with control Rm5000 nodules, a larger interzone II-III containing typical amyloplast-rich cells (Fig. 4C) was observed in MK5003 nodules. No clear zone III was observed, and the senescent zone IV appeared to be adjacent to interzone II-III. Ultrastructural studies showed that, in most plant cells, bacteria were correctly released from infection threads and they differentiated into type 2 and type 3 bacteroids (Fig. 4D). However, bacteroids were more sparsely distributed in MK5003-infected cells than in Rm5000-infected cells, and some bacteroids were irregular in shape (Fig. 4D). In a few cells, bacteroids of type 4 were observed confirming the fix + phenotype of the MK5003 strain (Sigaud et al. 1999). Moreover, in some infected cells of the interzone II-III, some bacteroids of type 1 directly underwent senescence and contained high amounts of polyhydroxybutyrate (Fig. 4E).

In MK5004 nodules, all plant cells were free of bacteroids despite the presence of many infection threads (Fig. 4F). A large number of amyloplasts were observed (Fig. 4G). Bacteria were released from infection threads without peribacteroid membrane and directly underwent senescence accumulating high amount of polyhydroxybutyrate (Fig. $4 \mathrm{H}$ ).

\section{DISCUSSION}

Production of reactive oxygen species appears to be a general response of plants to biotic and abiotic stress (Dat et al. 2000). In the case of alfalfa-Sinorhizobium meliloti symbiosis, superoxide radicals and hydrogen peroxide have been detected, especially in some infection threads (Santos et al. 2001) but never inside bacteria and bacteroids during the development of the root nodule. This suggests the presence of a very efficient bacterial $\mathrm{H}_{2} \mathrm{O}_{2}$-scavenging defense.

Unlike E. coli and Botrytis subtilis, which have been shown to contain two catalase isozymes, $S$. meliloti clearly expresses three genes encoding one bifunctionnal catalase-peroxidase KatB and two monofunctional catalases KatA and KatC. The $k a t B$ gene was cloned using a nested-PCR strategy followed by a genomic bank screening. This gene encodes a protein that shows clear homology to the group II of bacterial catalase-peroxidase (Loewen et al. 2000). Analysis using a recombinant strain harboring a katB::lacZ fusion showed no significant variation of $k a t B$ gene expression during growth of bacteria in rich medium. The noninducibility of katB in bacteria submitted to oxidative stress conditions tested in this paper is another major argument in support of the idea that KatB can be considered as a housekeeping bifunctional catalase-peroxidase enzyme in S. meliloti. A lower KatB activity is detectable in Rm1021 as compared with Rm5000 and GMI211 strains. It will be interesting to study whether there is a relationship between this phenotype and the substitution of the highly conserved Met364 by an arginine in the Rm1021 catalase-peroxidase sequence. Histochemical detection of $\beta$-galactosidase activity during nodule development revealed that katB is constitutively expressed in bacteria in infection threads, during infection of plant cells in zone II, in nitrogen-fixing bacteroids of zone III, and during senescence of the nodule. However, KatB does not seem to be essential to the symbiotic process, since efficient nitrogen-fixing nodules developed on roots of plants infected with the null $k a t B$ mutant. A large divergence in the structure of the $k a t B$ allele is observed between $S$. meliloti and M. loti, the two rhizobacteria for which the complete genome is available. In $M$. loti, the katB-homologous gene is localized on the chromosome and divergently arranged from an $o x y R$-like gene, which is known to encode the peroxide-sensing transcription factor essential for the induction of $k a t G$ encoding the HPI bifunctional catalase-peroxidase in Enterobacteria (Zheng and Storz 2000). In the $S$. meliloti genome, only one oxyR-like gene is present and is localized on the chromosome divergently upstream of katA and not upstream of katB. This could explain why only katA is inducible by exogenous $\mathrm{H}_{2} \mathrm{O}_{2}$ in $\mathrm{S}$. meliloti.

The katA transcription is largely induced during exponential phase. This expression pattern in free-living cells is similar to that of katG in E. coli, suggesting that a significant amount of the homeostatic control of intracellular $\mathrm{H}_{2} \mathrm{O}_{2}$ concentration during exponential growth seems to be accomplished by the transcriptional regulation of katA in S. meliloti. KatA is also the major catalase gene expressed in bacteroids, indicating that the nitrogen-fixation process induces a strong oxidative stress, probably due to the high rate of bacteroid respiration and to the stringent conditions required to reduce nitrogen. However, we cannot exclude the possibility that the protective role of katA activation in bacteroids is a population-wide phenomenon rather than one restricted to cells occasionally undergoing more intense oxidative stress, as has been demonstrated for OxyR activation in E. coli (Gonzalez-Flecha and Demple 1997). Two 
potential NifA and OxyR binding sites are present upstream of katA, suggesting that katA could be regulated at least by these two regulators. Unexpectedly, no detection of the expression of katA::lacZ fusion was observed in bacteria inside the infection threads, despite the detection of $\mathrm{H}_{2} \mathrm{O}_{2}$ all around the bacteria in some infection threads (Santos et al. 2001). This could suggest that the accumulation of the $\mathrm{H}_{2} \mathrm{O}_{2}$ levels in infection threads is not sufficient to induce the transcription of katA. However, fol-
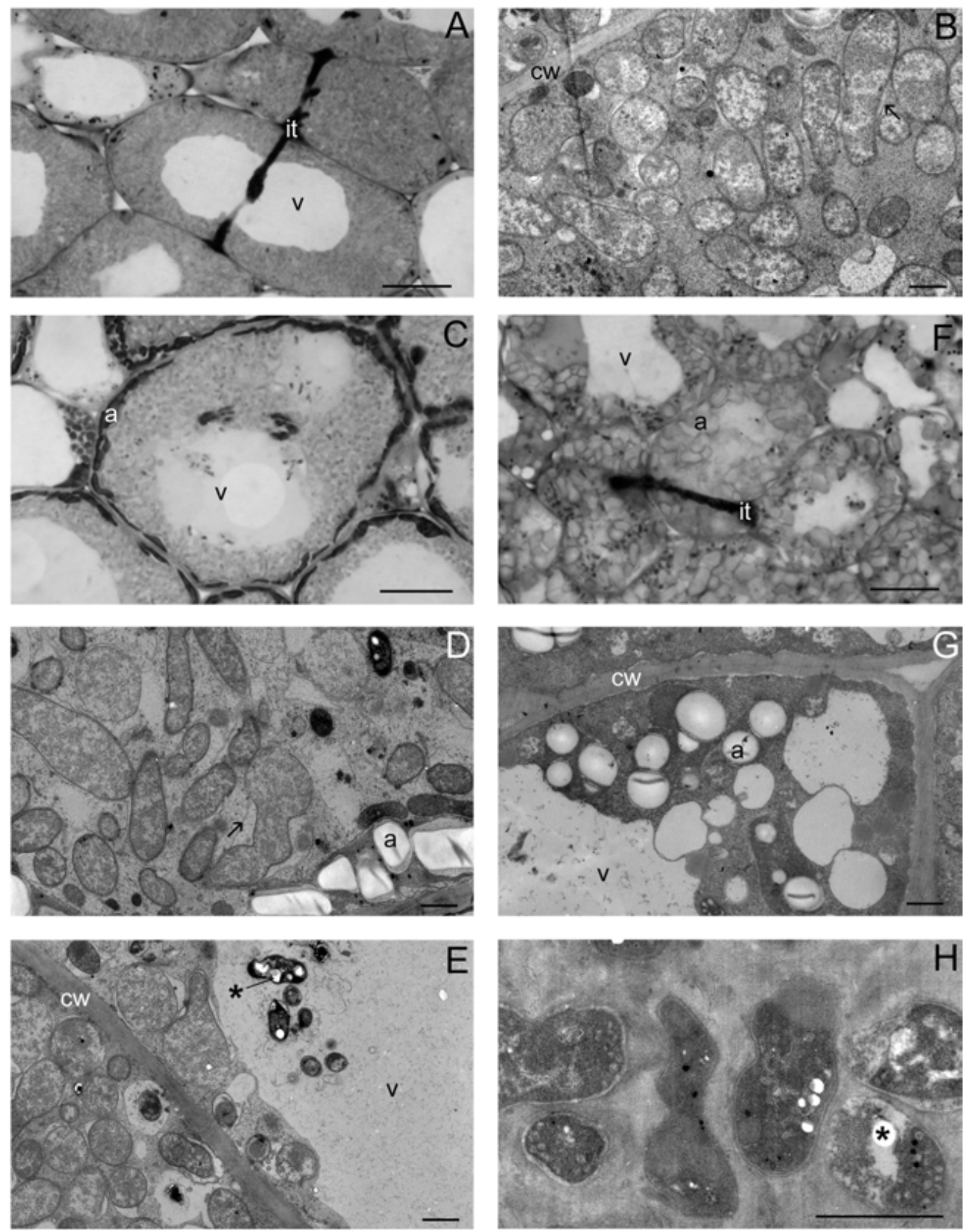

Fig. 4. Structure and ultrastucture of 5-week-old alfalfa nodules. Nodules were incited by $\mathbf{A}$ and B, Rm5000; C, D, and E, MK5003; and F, G, and H, MK5004 bacteria strains. Studies were performed at structural (A, C, and F) and ultrastructural (B, D, E, G, and H) levels. a = amyloplast; cw = cell wall; it $=$ infection thread; and $\mathrm{v}=$ vacuole. Arrows indicate peribacteroid membranes and * indicate polyhydroxybutyrate white granules $(\mathrm{E}$ and $\mathrm{H})$. Scale bars $=20 \mu \mathrm{m}(\mathrm{A}, \mathrm{C}$, and $\mathrm{F})$ and $1 \mu \mathrm{m}(\mathrm{B}, \mathrm{D}, \mathrm{E}, \mathrm{G}$, and $\mathrm{H})$. 
lowing treatment of root hairs showing infection threads with different concentrations of exogenous $\mathrm{H}_{2} \mathrm{O}_{2}$, no induction of katA was observed that is comparable to our results on free-living bacteria in stationary growth. On the other hand, our analysis using katC::lacZ fusion showed that $k a t C$ is expressed not only in late exponential and stationary phases in batch culture but also in all infection threads. Moreover, the analysis of the bacterial growth rate inside the infection thread using a $S$. meliloti strain that constitutively expresses a variant of green fluorescent protein indicated a bacterial doubling time of about $11 \mathrm{~h}$, which may reflect slower, or nonexponential, growth (Gage et al. 1996). All these results indicate that bacteria inside the infection thread are in a similar physiological state to free cells in stationary phase. The limitation of the bacterial growth in the infection threads could be due to peroxide-driven cross-linking of root nodule extensins as recently proposed (Rathbun et al. 2002; Wisniewski et al. 2000). Finally, katC is also expressed in vegetative bacteria released in the cells of the highly senescent zone IV of mature 6week-old nodules, which has been recently designated as an additional zone V (Timmers et al. 2000). Moreover, the absence of katA expression in zone $\mathrm{V}$ correlated with the fact that intracellular Rhizobia in zone $\mathrm{V}$ do not appear to fix nitrogen (Timmers et al. 2000).

Our results show that the catalase activity profiles during growth of free-living wild-type bacteria and after differentiation into bacteroids are correlated with the expression of the reporter gene lacZ in each kat-lacZ strain, suggesting that all catalases are mainly regulated at the transcriptional level in $S$. meliloti. However, it can not be excluded that the disruption of each kat gene, by insertion of promoterless lacZ gene, could lead to an artificial over-induction of the reporter gene by increasing oxidative stress in recombinant strains.
Does a relationship exist between the in planta expression profiles of each kat gene and the phenotype of recombinant kat mutants? All simple kat null mutants in different genetic backgrounds show a nod+ and fix+ phenotype. This could be due to the fact that, in each different region of nodules, at least two kat genes are expressed. In contrast, the disruption of two kat genes induces numerous problems during the nodulation or nitrogen fixation process, or both. Only 75 and $45 \%$ of the plants inoculated with the katA katC (MK5003) and katB katC (MK5004) double mutant strains, respectively, showed a nodulating phenotype. A decrease in the nitrogen fixation capacity was observed for MK5003-nodulated plants (Sigaud et al. 1999). This phenotype is probably due to a very bad differentiation of bacteroids into a type 4 nitrogen-fixing form in infected cells. A more drastic decrease in nitrogen fixation capacity was observed for the MK5004 mutant since the bacteria are not correctly released into plant cells, showed no peribacteroid membrane, and did not differentiate into bacteroids, indicating that the expression of $k a t B$ and $k a t C$ genes are essential for an efficient infection of plant cells. Compared with many mutants already described (Oke and Long 1999), the katB katC double mutant shows some similarities with the BacA mutant strain (Glazebrook et al. 1993). As yet, the effects of the disruption of $k a t A$ and $k a t B$ can not be analyzed, since the construction of this double mutant by transduction or conjugation has failed so far. This could indicate that both genes are probably essential for survival of bacteria on LB plates, since only these two kat genes are expressed during the exponential growth phase.

All these results indicate that sophisticated regulation of the kat genes occurs not only in batch culture, as for many other bacteria, but also during the establishment and the maintenance of functional symbiotic root nodules in alfalfa. Our studies on

Table 1. Bacterial strains and plasmids used in this study

\begin{tabular}{|c|c|c|}
\hline Strain or plasmid & Relevant characteristics ${ }^{a}$ & References \\
\hline \multicolumn{3}{|l|}{ Strains } \\
\hline \multicolumn{3}{|c|}{ Sinorhizobium meliloti } \\
\hline RCR2011 & SU47, wild type, $\mathrm{Nod}^{+} \mathrm{Fix}^{+}$ & Rosenberg et al. 1981 \\
\hline Rm1021 & Derivative of RCR2011, $\mathrm{Sm}^{\mathrm{r}}$ & S. Long \\
\hline $\operatorname{Rm} 5000$ & SU47, rif-5 & Finan et al. 1984 \\
\hline GMI211 & Derivative of RCR2011, lac, $\mathrm{Sm}^{\mathrm{r}}$ & Niel et al. 1977 \\
\hline GKAZ01 & Same as GMI211 but with pkatA-lacZ fusion & This study \\
\hline GKBZ01 & Same as GMI211 but with pkatB-lacZ fusion & This study \\
\hline GKCZ01 & Same as GMI211 but with pkatC-lacZ fusion & This study \\
\hline MK5002 & Same as $\mathrm{Rm} 5000$ but with katC:: $\Omega \mathrm{Sm}^{\mathrm{r}} / \mathrm{Sp}^{\mathrm{r}}$ & Sigaud et al. 1999 \\
\hline MK5003 & Same as MK5002 but with katA::Tn5 & Sigaud et al. 1999 \\
\hline MK5004 & Same as MK5002 but with pkatB-lacZ fusion & This study \\
\hline \multicolumn{3}{|l|}{ Escherichia coli } \\
\hline DH5 $\alpha$ & F supE44 AlacU169( D80dlacZDM15) hsdR17( $\left.r_{\mathrm{K}}{ }^{-} m_{\mathrm{K}}{ }^{+}\right)$recA1 endA1 gyrA96 thi-1 relA1 & Bethesda Research Laboratories \\
\hline MT607 & pro-82 thi-1 hsd $\mathrm{R} 17$ supE44 recA56 & Finan et al. 1986 \\
\hline MT616 & MT607 (pRK600) & Finan et al. 1986 \\
\hline \multicolumn{3}{|l|}{ Plasmids } \\
\hline pLAFR1 & IncP1 cosmid cloning vector $\mathrm{Tc}^{\mathrm{r}}$ & Friedman et al. 1982 \\
\hline pRK600 & ColE1 replicon with $\mathrm{RK} 2$ transfer region $\mathrm{Cm}^{\mathrm{r}}$ & Finan et al. 1986 \\
\hline pBluescriptKS(+) & Derivative of pUC19 with f1(+)oriR, $\mathrm{Ap}^{\mathrm{r}}$ & Stratagene, La Jolla, CA. U.S.A. \\
\hline pGEM-T & $\mathrm{T}$ vector with $\mathrm{f} 1$ ori $\mathrm{R}, \mathrm{Ap}^{\mathrm{r}}$ & Promega Corp. \\
\hline pSUP202 & ColE1, Mob+, $\mathrm{Tc}^{\mathrm{r}} \mathrm{Ap}^{\mathrm{r}} \mathrm{Cm}^{\mathrm{r}}$ & Simon et al. 1983 \\
\hline pKOK5 & $\mathrm{Ap}^{\mathrm{r}} \mathrm{Km}^{\mathrm{r}}$, pSUP202 derivative; source of lacZ-Km ${ }^{\mathrm{r}}$ & Kokotek and Lotz 1989 \\
\hline pLRK3 & pLAFR1, S. meliloti cosmid with katB & This study \\
\hline pLRK4 & pLAFR1, S. meliloti cosmid with katB & This study \\
\hline pBSKB1 & pBluescript, 3.0-kb SmaI-ApaI fragment with katB & This study \\
\hline pBSKB2 & pBluescript, 2.4-kb EcoRV-ApaI fragment with katB & This study \\
\hline pGEMKB & pGEM-T, with 581-bp PCR-amplified fragment of katB & This study \\
\hline pBSKBZ & Same as pBSKB1 but with katB::lacZ & This study \\
\hline \multirow[t]{2}{*}{ pSUPKBZ } & pSUP202, BamHI-BamHI fragment of pBSKBZ & This study \\
\hline & Complementation katB- & \\
\hline pBSKA1-1 & pBluescript, 1.4-kb EcoRI-ApaI fragment with partial katA & Hérouart et al. 1996 \\
\hline pBSKAZ & Same as pBSKA1-1 but with katA::lacZ & This study \\
\hline pSUPKAZ & pSUP202, PstI-PstI fragment of pBSKAZ & This study \\
\hline
\end{tabular}

\footnotetext{
${ }^{a}$ Abbreviations: Tc, tetracycline; Sm, streptomycin; Ap, ampicillin; Km, kanamycin; Cm, chloramphenicol; and Sp, spectinomycin.
} 
the $k a t B$ kat $C$ double mutant strain confirm the critical protective role of these two catalases during the infection process. We further propose that these genes could also be used as makers to evaluate the physiological response of bacteroids in nodulated plants submitted to different environmental conditions leading to oxidative stress.

\section{MATERIALS AND METHODS}

\section{Bacteria strains and growth conditions.}

The bacterial strains and plasmids used are listed in Table 1. Sinorhizobium meliloti was grown in LB-MC medium as described previously (Hérouart et al. 1996). Antibiotics are added as required at the following concentration $(\mu \mathrm{g}$ per $\mathrm{ml})$ : ampicillin (100), chloramphenicol (30), kanamycin (50), neomycin (200), spectinomycin (100), streptomycin (100), and tetracycline (10).

\section{General molecular techniques.}

The molecular cloning techniques, gel electrophoresis, and small-scale preparation of total DNA from $S$. meliloti were essentially performed according to Ausubel and associates (1993). Plasmid DNA and DNA fragments were purified by using Qiagen kit and Quiaex kit, respectively (Qiagen, Courtaboeuf, France). Sequence alignments and analysis were performed using bioinformatics tools of NCBI and INFOBIOGEN servers.

\section{Cloning of the S. meliloti katB.}

To perform nested-PCR, three different homology boxes were chosen in the consensus sequence: peptide 1 (IYVNPEG), peptide 2 (MNDEETVA), and peptide 3 (HRDMGP). The three degenerated oligonucleotides katB1 (5'ATHTAYGTNAAYCCNGARGG), katB2 (5'GCNRCNGTYTCNWCRTCRTYCAT), and katB3 (5'GGNCCCATRTCNCKRTG) corresponding respectively to peptides 1 (IYVNPEG), 2 (MNDEETVA), and 3 (HRDMGP) were synthesized. A first PCR with katBl and katB3 primers was performed on S. meliloti total DNA using the protocol previously described (Hérouart et al. 1996). The size of the amplified fragment was $581 \mathrm{bp}$, which corresponded to the predicted size from the sequence alignment. Using this fragment as a template, a second PCR using katB1 and katB2 produced a 108-bp fragment, as expected. The PCR-amplified 581-bp fragment (SmkatB) was subcloned into pGEM-T vector, sequenced, and ${ }^{32} \mathrm{P}$-labeled with the prime-a-gene labeling system (Promega, Charbonnières, France). Screening of 3,000 colonies of the genomic cosmid library was performed as described previously (Hérouart et al. 1996). Two positive clones (pLRK3 and pLRK4) carried an insert of $22 \mathrm{~kb}$ exhibiting the same restriction map. Southern blotting and deletion analysis of the positive cosmid pLRK3 allowed the localization of $k a t B$ on a 3-kb SmaI-ApaI DNA fragment (subclone pBSKB1).

\section{Construction of a katB mutant strain (GKBZ01).}

Plasmid pBSKB2 carries the 2.4-kb EcoRI-ApaI fragment purified from pBSKB1 and subcloned into pBluescript KS (+). The coding region of $k a t B$ was disrupted by insertion of a promoterless lacZ-Km ${ }^{\mathrm{r}}$ cartridge, allowing also the construction of a katB-lacZ fusion. A BamHI-BamHI fragment containing the cartridge was purified from plasmid pKOK5 and inserted in the $B g l$ II site of pBSKB2, giving the pBSKBZ plasmid. Using the two BamHI sites, which were present in the polylinker of the vector and in the katB gene, the katB-lacZ fusion was cloned at the unique BamHI of the vector pSUP202, resulting in the pSUPKBZ plasmid. The recombinant suicide plasmid was transferred to the GMI211 recipient strain by triparental mating using the MT616 E. coli strain as a helper, as described previously (Glazebrook and Walker 1991). Simple recombinant clones were selected on LB-MC medium containing streptomycin, neomycin, and X-gal. Recombination at the correct location was checked by Southern hybridizations using the $E c o$ RI-BamHI fragment of the $k a t B$ gene as a probe. One $S$. meliloti clone, noted GKBZ01, was selected for further studies.

\section{Construction of the katA::lacZ fusion (strain GKAZ01).}

To construct a transcriptional lacZ fusion to the katA promoter, the plasmid pKOK5 DNA was digested with PstI and the lacZ-Km ${ }^{\mathrm{r}}$ cartridge was inserted in the NsiI site of pBSKA1-1, which has been shown to carry partial katA (Hérouart et al. 1996). The PstI-PstI fragment of the recombinant plasmid harboring the correct katA::lacZ orientation was inserted in the unique PstI site of pSUP202. After triparental conjugation using GMI211 as recipient, simple recombinant clones were selected on LB-MC medium containing tetracycline, neomycin, and X-Gal. After Southern checking of a correct recombination, one $S$. meliloti clone, noted GKAZ01, was selected for further studies.

\section{Construction}

of the katB katC double mutant (strain MK5004).

To construct the katB katC double mutant, the suicide plasmid pSUPKBZ was transferred to the katC mutant MK5002 recipient strain (Sigaud et al. 1999) by triparental mating using the MT616 E. coli strain as a helper, as described previously (Glazebrook and Walker 1991). Simple recombinant clones were selected on LB-MC medium containing streptomycin, spectinomycin, and neomycin. Recombination was verified by Southern hybridizations with the EcoRI-BamHI fragment of the $k a t B$ gene as probe, and one $S$. meliloti clone, noted MK5004, was selected for further studies.

\section{Plant nodulation assays.}

Medicago sativa L. var. Europe (alfalfa) was used as host plant to test nodulation and nitrogen fixation of S. meliloti strains. Surface-sterilized germinating seedlings were grown in test tubes and were inoculated with the appropriate strain by using the protocol described previously (Hérouart et al. 1996). Nitrogenase activity was determined by acetylene reduction using a gas chromatograph as described by Rigaud (1976).

\section{Enzyme activity assays and oxidative stress conditions.}

Bacterial crude extracts were prepared from free-living bacteria by sonication in a phosphate buffer (Hérouart et al. 1996). Total catalase activity was measured spectrophotometrically by following the decomposition of $\mathrm{H}_{2} \mathrm{O}_{2}$ at $240 \mathrm{~nm}$ (Jones 1982). Catalase was visualized on nondenaturating polyacrylamide gels by inhibition of diaminobenzidine oxidation, as previously described (Clare et al. 1984; Hérouart et al. 1996). Protein concentration was determined by the Bradford method using bovine serum albumin as standard (Bradford 1976). $\beta$-galactosidase activity in crude extracts of bacteria and nodules was carried out using o-nitrophenyl- $\beta$-D-galactoside as the substrate, according to Miller's method (Miller 1972). Histochemical detection of $\beta$-galactosidase activity in entire roots and in cross sections was performed as described previously (Boivin et al. 1990). Sections of nodules $(150 \mu \mathrm{M})$ were cut with a vibratome 1000 Plus (Labonord, Templemars, France) and were mounted on slides for observation and photography with an Olympus microscope. To evaluate the effect of different oxidative stresses on the regulation of catalase gene expression in GKAZ01, GKBZ01, and GKCZ01 strains, bacteria have been inoculated at optical density at $600 \mathrm{~nm}\left(\mathrm{OD}_{600}\right)=$ 0.05 in LB-MC medium, grown overnight until $\mathrm{OD}_{600}=0.4$, 
and submitted for $1 \mathrm{~h}$ to heat stress, salt stress, ethanol, paraquat, or $\mathrm{H}_{2} \mathrm{O}_{2}$. Values were obtained by using triplicate samples.

\section{Electron microscopy studies.}

For electron microscopy, nodules were harvested 5 weeks after inoculation. At least five nodules from different plants were fixed, post-fixed, dehydrated, and embedded, as described previously (Santos et al. 2000). Sections were performed with a diamond knife in a Reichert Ultracut Ultramicrotome (Leica, Rueil-Malmaison, France). After staining with uranyl acetate and Reynold's lead citrate, ultrathin sections were examined in a transmission electron microscope (CM12; Philips, Cambridge, U.K.).

\section{ACKNOWLEDGMENTS}

The authors are grateful to J. Harrison for helpful discussion. This work was supported by the Improving Human Potential European Program (contract HPRN-CT-2000-00094).

\section{LITERATURE CITED}

Ausubel, F. M., Brent, R., Kingston, R. E., Moore, D. D., Seidman, J. G., Smith, J. A., and Struhl, K. 1993. Current Protocols in Molecular Biology. Greene Publishing Associates, New York.

Barnett, M. J., Fisher, R. F., Jones, T., Komp, C., Abola, A. P., BarloyHubler, F., Bowser, L., Capela, D., Galibert, F., Gouzy, J., Gurjal, M., Hong, A., Huizar, L., Hyman, R. W., Kahn, D., Kahn, M. L., Kalman, S., Keating, D. H., Palm, C., Peck, M. C., Surzycki, R., Wells, D. H., Yeh, K. C., Davis, R. W., Federspiel, N. A., and Long, S. R. 2001. Nucleotide sequence and predicted functions of the entire Sinorhizobium meliloti pSymA megaplasmid. Proc. Natl. Acad. Sci. U.S.A. 98:9883-9888.

Boivin, C., Camut, S., Malpica, C. A., Truchet, G., and Rosenberg, C. 1990. Rhizobium meliloti genes encoding catabolism of trigonelline are induced under symbiotic conditions. Plant Cell 2:1157-1170.

Bradford, M. M. 1976. A rapid and sensitive method for the quantitation of microgram quantities of protein utilizing the principle of proteindye binding. Anal. Biochem. 72:248-254.

Clare, D. A., Duong, M. N., Darr, D., Archibald, F., and Fridovich, I. 1984. Effects of molecular oxygen on detection of superoxide radical with nitroblue tetrazolium and on activity stains for catalase. Anal. Biochem. 140:532-537.

Crockford, A. J., Davis, G. A., and Williams, H. D. 1995. Evidence for cell-density-dependent regulation of catalase activity in Rhizobium leguminosarum bv. phaseoli. Microbiology 141:843-851.

Dat, J., Vandenabeele, S., Vranova, E., Van Montagu, M., Inze, D., and Van Breusegem, F. 2000. Dual action of the active oxygen species during plant stress responses. Cell Mol. Life Sci. 57:779-795.

Finan, T. M., Hartweig, E., LeMieux, K., Bergman, K., Walker, G. C., and Signer, E. R. 1984. General transduction in Rhizobium meliloti. J. Bacteriol. 159:120-124.

Finan, T. M., Kunkel, B., De Vos, G. F., and Signer, E. R. 1986. Second symbiotic megaplasmid in Rhizobium meliloti carrying exopolysaccharide and thiamine synthesis genes. J. Bacteriol. 167:66-72.

Friedman, A. M., Long, S. R., Brown, S. E., Buikema, W. J., and Ausubel, F. M. 1982. Construction of a broad host range cosmid cloning vector and its use in the genetic analysis of Rhizobium mutants. Gene 18:289-296.

Gage, D. J., Bobo, T., and Long, S. R. 1996. Use of green fluorescent protein to visualize the early events of symbiosis between Rhizobium meliloti and alfalfa (Medicago sativa). J. Bacteriol. 178:7159-7166.

Galibert, F., Finan, T. M., Long, S. R., Puhler, A., Abola, P., Ampe, F., Barloy-Hubler, F., Barnett, M. J., Becker, A., Boistard, P., Bothe, G., Boutry, M., Bowser, L., Buhrmester, J., Cadieu, E., Capela, D., Chain, P., Cowie, A., Davis, R. W., Dreano, S., Federspiel, N. A., Fisher, R. F., Gloux, S., Godrie, T., Goffeau, A., Golding, B., Gouzy, J., Gurjal, M., Hernandez-Lucas, I., Hong, A., Huizar, L., Hyman, R. W., Jones, T., Kahn, D., Kahn, M. L., Kalman, S., Keating, D. H., Kiss, E., Komp, C., Lelaure, V., Masuy, D., Palm, C., Peck, M. C., Pohl, T. M., Portetelle, D., Purnelle, B., Ramsperger, U., Surzycki, R., Thebault, P., Vandenbol, M., Vorholter, F. J., Weidner, S., Wells, D. H., Wong, K., Yeh, K. C., and Batut, J. 2001. The composite genome of the legume symbiont Sinorhizobium meliloti. Science 293:668-672.

Glazebrook, J., and Walker, G. C. 1991. Genetic techniques in Rhizobium meliloti. Methods Enzymol. 204:398-418.

Glazebrook, J., Ichige, A., and Walker, G. C. 1993. A Rhizobium meliloti homolog of the Escherichia coli peptide-antibiotic transport protein SbmA is essential for bacteroid development. Genes Dev. 7:14851497.

Gonzalez-Flecha, B., and Demple, B. 1997. Homeostatic regulation of intracellular hydrogen peroxide concentration in aerobically growing $E s$ cherichia coli. J. Bacteriol. 179:382-388.

Hérouart, D., Sigaud, S., Moreau, S., Frendo, P., Touati, D., and Puppo, A. 1996. Cloning and characterization of the katA gene of Rhizobium meliloti encoding a hydrogen peroxide-inducible catalase. J. Bacteriol. 178:6802-6809.

Jones, D. P. 1982. Intercellular catalase function: Analysis of the catalytic activity by product formation in isolated liver cells. Arch. Biochem. Biophys. 214:806-814.

Kokotek, W., and Lotz, W. 1989. Construction of a lacZ-kanamycin-resistance cassette, useful for site-directed mutagenesis and as a promoter probe. Gene 84:467-471.

Lerouge, P., Roche, P., Faucher, C., Maillet, F., Truchet, G., Prome, J. C., and Denarie, J. 1990. Symbiotic host-specificity of Rhizobium meliloti is determined by a sulphated and acylated glucosamine oligosaccharide signal. Nature 344:781-784.

Loewen, P. C., Klotz, M. G., and Hassett, D. J. 2000. Catalase-an "old" enzyme that continues to surprise us. ASM News 66:76-82.

Long, S. R. 1996. Rhizobium symbiosis: Nod factors in perspective. Plant Cell 8:1885-1898.

Miller, J. H. 1972. Experiments in Molecular Genetics. Cold Spring Harbor Laboratory Press, Cold Spring Harbor, NY, U.S.A.

Niel, C., Guillaume, J. B., and Bechet, M. 1977. Mise en évidence de deux enzymes présentant une activité $\beta$-galactosidase chez Rhizobium meliloti. Can. J. Microbiol. 23:1178-1181.

Ohwada, T., Shirakawa, Y., Kusumoto, M., Masuda, H., and Sato, T. 1999. Susceptibility to hydrogen peroxide and catalase activity of root nodule bacteria. Biosci. Biotechnol. Biochem. 63:457-462.

Oke, V., and Long, S. R. 1999. Bacteroid formation in the Rhizobium-legume symbiosis. Curr. Opin. Microbiol. 2:641-646.

Rathbun, E. A., Naldrett, M. J., and Brewin, N. J. 2002. Identification of a family of extensin-like glycoproteins in the lumen of Rhizobium-induced infection threads in pea root nodules. Mol. Plant-Microbe Interact. 15:350-359.

Rigaud, J. 1976. Effet des nitrates sur la fixation d'azote par des nodules de Haricots (Phaseolus vulgaris L.). Physiol. Vég. 14:297-308.

Rosenberg, C., Boistard, P., Denarie, J., and Casse-Delbart, F. 1981. Genes controlling early and late functions in symbiosis are located on a megaplasmid in Rhizobium meliloti. Mol. Gen. Genet. 184:326-333.

Santos, R., Bocquet, S., Puppo, A., and Touati, D. 1999. Characterization of an atypical superoxide dismutase from Sinorhizobium meliloti. J. Bacteriol. 181:4509-4516.

Santos, R., Hérouart, D., Puppo, A., and Touati, D. 2000. Critical protective role of bacterial superoxide dismutase in Rhizobium-legume symbiosis. Mol. Microbiol. 38:750-759.

Santos, R., Hérouart, D., Sigaud, S., Touati, D., and Puppo, A. 2001. Oxidative burst in alfalfa-Sinorhizobium meliloti symbiotic interaction. Mol. Plant-Microbe Interact. 14:86-89.

Sigaud, S., Becquet, V., Frendo, P., Puppo, A., and Hérouart, D. 1999. Differential regulation of two divergent Sinorhizobium meliloti genes for HPII-like catalases during free-living growth and protective role of both catalases during symbiosis. J. Bacteriol. 181:2634-2639.

Simon, R., Priefer, U., and Pülher, A. 1983. A broad host range mobilization system for in vivo genetic engineering: Transposon mutagenesis in gram negative bacteria. Bio/Technology 1:784-791.

Stougaard, J. 2000. Regulators and regulation of legume root nodule development. Plant Physiol. 124:531-540.

Timmers, A. C., Soupene, E., Auriac, M. C., de Billy, F., Vasse, J., Boistard, P., and Truchet, G. 2000. Saprophytic intracellular rhizobia in alfalfa nodules. Mol. Plant-Microbe Interact. 13:1204-1213.

Vasse, J., de Billy, F., Camut, S., and Truchet, G. 1990. Correlation between ultrastructural differentiation of bacteroids and nitrogen fixation in alfalfa nodules. J. Bacteriol 172:4295-4306.

Wisniewski, J. P., Rathbun, E. A., Knox, J. P., and Brewin, N. J. 2000. Involvement of diamine oxidase and peroxidase in insolubilization of the extracellular matrix: Implications for pea nodule initiation by Rhizobium leguminosarum. Mol Plant-Microbe Interact. 13:413-420.

Zheng, M., and Storz, G. 2000. Redox sensing by prokaryotic transcription factors. Biochem. Pharmacol. 59:1-6. 